\title{
The Roles of Landscape Features in Re-Making Sense of Place in Mosul City Centre
}

\author{
Musaab Sami Al-Obeidy \\ Assistant Lecturer, Architectural Engineering \\ Cihan University - Sulaimaniya \\ arch.musaabsami@gmail.com
}

\author{
Shuhana Shamsuddin \\ Professor, Department of Civil Engineering \\ University Technology Malaysia \\ shuhana.kl@utm.my
}

\begin{abstract}
Due to the unfit development of street characteristics, and negligence of maintenance, street loss what is precious and its sense, here the people's feelings and perception of the streets have been negatively affected. This paper highlights landscape features as physical characteristics of streets including soft landscape (trees) and hard landscape (street furniture). This is to identify the roles of these two types of landscape features in securing sense of place. Nineveh Street in Mosul City Center, Iraq is selected as a case study. Mixed methods were selected for this research, quantitative technique by using 330 questionnaire survey, and qualitative technique by using 30 semi-structured interviews and direct observation. The study concludes that landscape features of streets contribute to create sense of safety and comfort that in turns give sense of place. The lack of the role of landscape features in providing safety and comfort has a negative effect on reducing the influence of sense of place in the street.
\end{abstract}

Keywords: landscape features, sense of place, commercial streets.

\section{INTRODUCTION}

Streets are an important part of open public spaces that reflect the character and the sense of place of cities [1]. Streets have many functions that give them their sense of place, thus this sense is reflected generally in the city. Meanwhile, the physical characteristics of streets, such as building and landscape features, contribute to make the street safe, comfortable [2] and [3]. Nowadays, rapid development has made an impact towards streets' development that acts as a public space, particularly the streets of the city centres. In Iraq, Mosul City Centre has witnessed a negligence crisis that can threaten the character of the city and reduce the physical roles of public spaces [4]. Although, in the last years, there were serious attempts by architects, planners, and sociologists for renewal and rehabilitation, but until now Mosul City Centre has not witnessed factual and visual changes in its context. This issue puts the architects and designers in front of difficult challenges to strengthen the character, identity, and sense of place of Mosul City Centre. Hence, this study is significant in further informing the street character of the city.

The author of study [4] explained some problems of Mosul's scenario. He confirms that Mosul City has suffered from the lack of thoughtful maintenance, causing the demise of many of its ancient monuments, besides the repulsion of its buildings, lack of feeling secure, and the large number of un-aesthetic, undesirable scenes. He also mentioned that the presence of negligence and the destruction of what remains of landmarks, such as buildings, has led to the collapse of the traditional environment in Mosul City Centre.

The narrowness of street pavements in Mosul City Centre, which is caused by the display of the goods on the sidewalk either by stall owners or shop owners, has led to the loss of the pavements' features in people's perception, thus pavements or sidewalks of the street lose their role as one of the landscape features which make the street recognisable [5]. Furthermore, the illegibility of the pavement and its narrowness force street users to leave the pavement and use the street for walking. This issue creates an uncomfortable environment for street users. Meanwhile, the street user faces difficulty for access when he wants to pass by or shop to [5].

However, due to the unfit development of street characteristics, the people's feelings and perception of the streets have been negatively affected. In most cases, changes in the physical setting, may consequently erase what is precious [6].

\section{LITERATURE REVIEW}

According to [2], landscape features are one of the physical elements of the place. It is generally natural physical characteristics [7]. Landscape features refer to soft landscape (trees) and hard landscape (street furniture) as suggested by [8], where soft landscape features are the landscape elements that represent nature such as plant, water and topography [8]. However, hard landscape was categorised as the manmade features designed to complement the soft landscape [9] and [10].

The success of any given place is highly influenced by the safety, comfort and convenience which people experience while pass through and/or go to places, spaces, and buildings [11]. According to [2], the presence of signs, lighting at night, sitting areas, trees, beautiful views, parking areas, facilities, and pavements with suitable width to walk on, contribute to making a comfortable environment. Their study reveals that natural 
elements play a significant role in contributing towards the positive feeling of the place, thus making it comfortable for its users. A comfortable environment is also associated with the quality of the view, which is created by river, vegetation, and topography, as suggest by [12] and [13]. The reflections of buildings along the river and the colourful lighting at night create a beautiful visual effect. Moreover, it has been proven from previous studies that trees create a good human relationship with nature and this creates a peaceful environment [14] and [15]. The researchers in reference [2] mentioned that mature trees are considered as a street symbol and contribute to the comfort of the environment.

According to [16], six features, namely; benches, dustbins, bicycle racks, bus stops, the quality of view, and pavements, contribute in making the environment in streets uncomfortable. It has been established that the attractiveness of the street decreases due to the presence of too much traffic management, which means that uncomfortable environment on streets is partially attributed to an over-presence of traffic lights [16]. Furthermore, the untidy appearance of transformer vaults and manholes adds to the decline in the quality of view, leading to an uncomfortable environment. According to [17], a sidewalk is an important feature; however, the vertical designation (level of changes) of it is not compulsory in the 'shared space' concept. This type of concept is suitable for streets with narrow width as in the study area.

On the other hand, to create a safe environment it is important to provide appropriate street lighting. This is consistent with the findings of [2], who found that positive and negative feelings are influenced by a feeling of safety, particularly through street lighting, the lack of which, especially at back lanes, creates an insecure feeling, while the opposite leads to a safe environment. Lighting assists in the protection of property, discourages vandalism and crime, and as a result residents and street users build a feeling of security [18]. Furthermore, [19] has observed that the, continuous presence of pedestrians along the way, the presence of security officers and a safe traffic environment, walkways that extend from one destination to another, and lighting at night all have a vital role in making the street a safe place.

\section{METHODS AND MATERIALS}

This research uses mixed methods, quantitative and qualitative techniques. Mixed methods were selected for this research because the two methods have strengths and weaknesses, thus it helps balance out any potential weaknesses in each data collection method [20]. In this matter, [21] motivate researchers to use mixed methods in doing their research because the combination of both forms of data (quantitative sense and qualitative sense) provides the most complete analysis of research problems.

The quantitative method used the 330 questionnaire surveys technique, based on $5.5 \%$ sampling error at $95 \%$ confidence level, which are employed by many considerable researchers [2], [3], [15], [19], [22], [23], and [24]. The questionnaire survey technique is defined by [25] as a formalised instrument for asking information directly from a respondent concerning behaviour, demographic characteristics, level of knowledge, and/or attitudes, beliefs, and feelings. The questionnaire survey of this study will ask respondents about their perception and feeling in identifying the role of landscape features of Nineveh Street in contributing to the sense of place. Besides, this study has employed 30 semi-structured interviews and direct observation. These two qualitative techniques are used to support findings that come out from the quantitative methods. According to [26], the interview is the most prominent data collection tool in qualitative research. It is a very good way of accessing people's perceptions, meanings, definitions of situations, and constructions of reality. One the other hand, the observation can give additional, and more accurate information on the behaviour of people compared to interviews or questionnaires, as [27] mentioned. This study uses direct observation to record and write notes, and evaluate the physical elements and features in the Nineveh Street in terms of landscape features. All data collection will work together to get convenient interpretations.

\section{CASE STUDY}

Nineveh Street is one of the first streets to be established in the beginning of the last century in the historical commercial centre of Mosul, particularly in 1917 [28]. It is the first street founded in the city in the beginning of the twentieth century with about two kilometres of length [29]. It is located within the main commercial district of Mosul City Centre, and in the core of Mosul City [29] and [30]. It was chosen based on the physical characteristics that represent the character of Mosul City Centre, after the first decade of the last century, which emerged after the British occupation of Mosul. Recently, Nineveh Street became one of the most important and famous commercial streets in Mosul City Centre [29] (See Figure 1). 


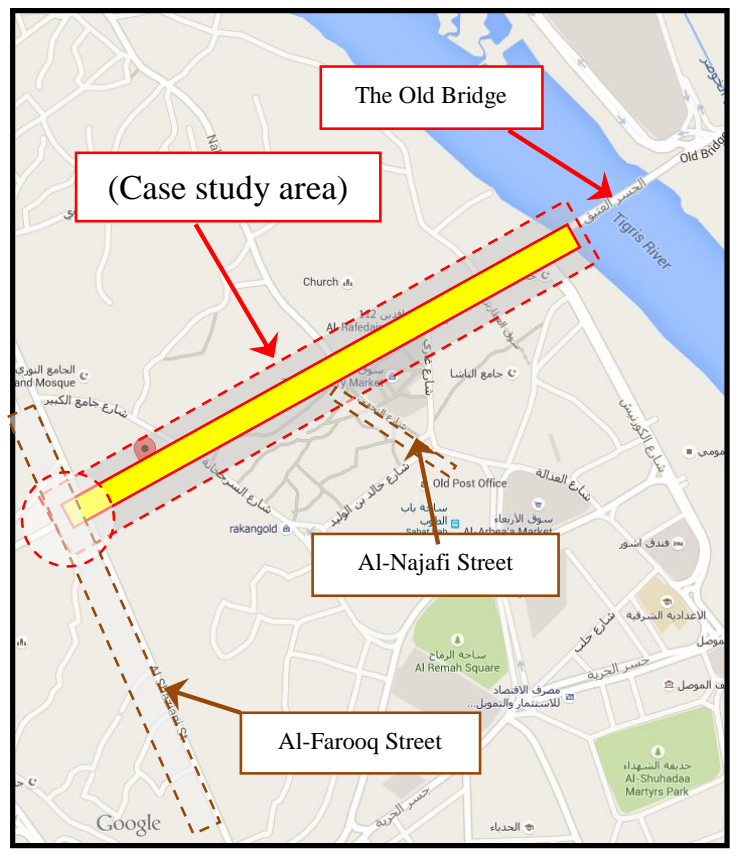

Figure 1: A Recent View of the Nineveh Street

\section{RESULTS \& DISCUSSION}

Landscape features are physical characteristic of commercial streets. These types of features contribute in making a sense of safety and a sense of comfort in places, thus giving a unique sense of place. According to conducted data, a total of 330 respondents participated in the survey, but only 319 questionnaire survey was used in analysis and interpretation due to having full answers. The majority of the survey respondents were aged between 18-24 and 25-49 years old whereas 75\% $(\mathrm{N}=240)$ of them were males and $25 \%(\mathrm{~N}=79)$ were females.

The Next part discusses the role of landscape features in making streets safe and comfortable, respectively.

\subsection{The Role of Landscape Features in Making the Street Safe}

Landscape features played an important role in making Nineveh Street safe to mobile and static users on this street. These features included the presence of security offices, the continuous presence of people along the way, walkway that extend from one place to another, good lighting system at night, the presence of a safe traffic environment, and no crimes and robberies. According to the survey, most of the respondents feel safe while on the street. The dominant reason that makes them feel safe was the continuous presence of people along the way which was mentioned by $70 \%(\mathrm{~N}=222)$ of the respondents (see Figure 2). This finding supports the opinion of [2] that the presence of people in a place is a feature that contributes to generating a safe environment in the street.

The presence of a safe traffic environment also contributed in making a safe environment. It was observed that there was only one traffic light at the Nineveh Street junction with Ghazi Street, and all junctions along Nineveh Street were without traffic lights (see Figure 3). Moreover, Nineveh Street is located at the centre of Mosul City, and many streets are linked with it. Thus, the presence of many vehicles throughout the day made this street crowded. The cars stopping or moving very slowly. This jam in Nineveh Street reduced dangerousness brought about by the speed of vehicles, thus raised the rate of sense of safety. This was mentioned by many respondents during the field interview.

In contrast, $26 \%(\mathrm{~N}=83)$ of the respondents felt unsafe on this street. The major reason behind this case was because of the presence of some crimes and robberies which were mentioned by around $39 \%(12 \%)$ of the respondents. Many interviewees considered the Street as an unsafe space because of some theft accidents that have occurred, especially on Fridays and Saturdays, which are the weekend days, during which the number of users increases.

Hence, it was apparent that the landscape features played a significant role in making Nineveh Street have a safe atmosphere. This also confirms [31] idea of landscape elements as important components of a street that contribute in making the street safe. 


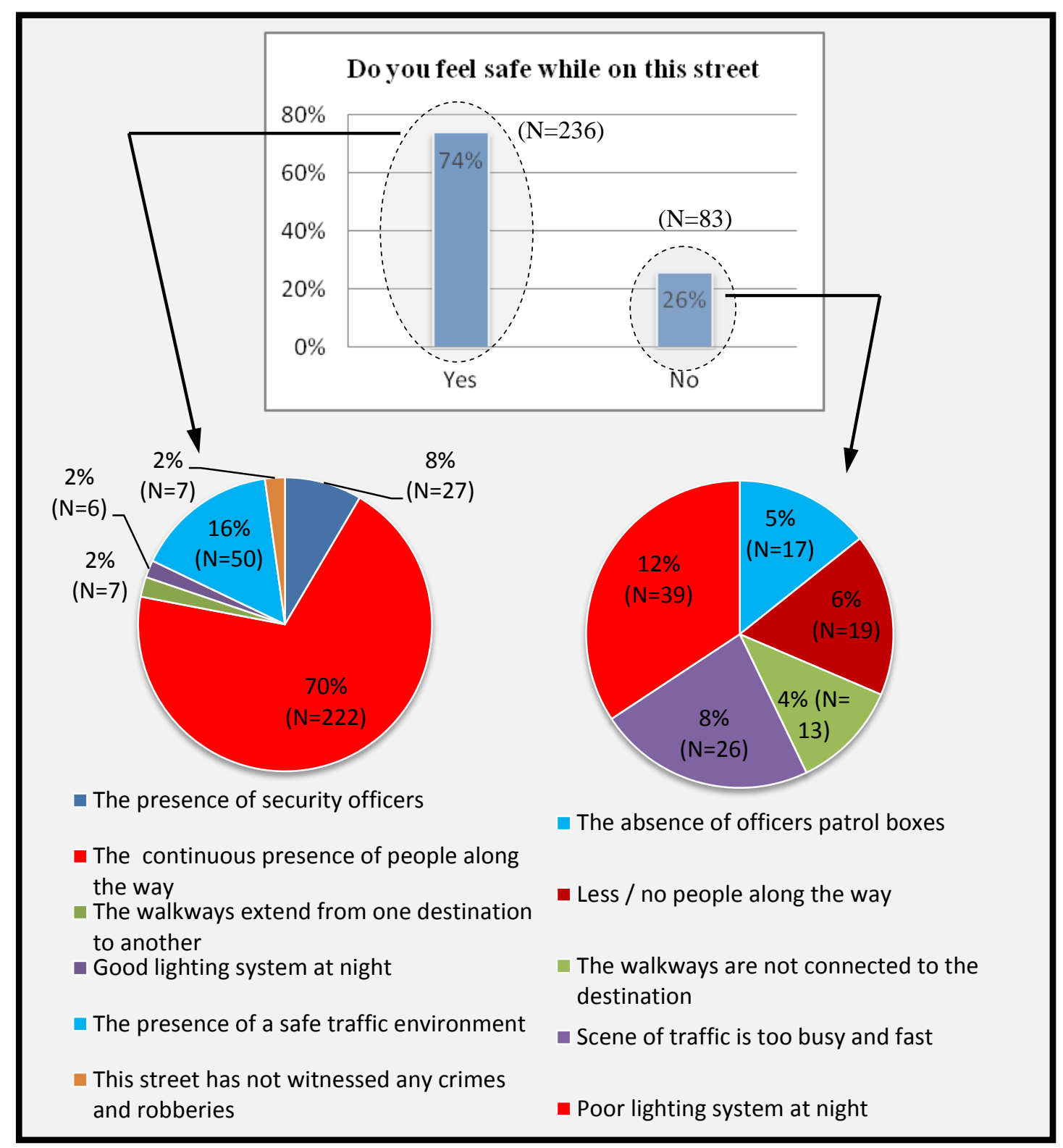

Figure 2: Reasons respondents feel safe and unsafe when they walk along the Street
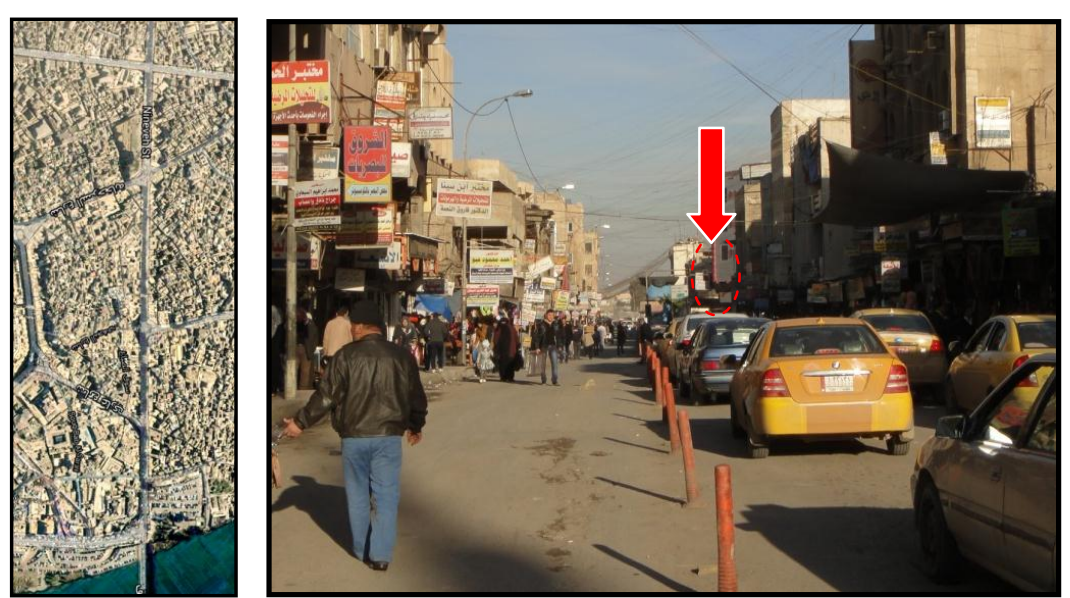

Figure 3: The only traffic light in Nineveh Street 


\subsection{The Role of Landscape Features in Making the Street Comfortable}

Landscape features played some role in making Nineveh Street comfortable to street users. The landscape features that contributed in making a comfortable environment included signs, traffic lights, lighting system, sitting area, shaded areas, beautiful views, comfortable pavement to walk on, the presence of parking areas, and the presence of public toilets.

According to the survey, more than half of the number of respondents felt uncomfortable when they walk along this street. The narrowness of pavement was the dominant reason that made $51 \%(\mathrm{~N}=162)$ of the respondents feel uncomfortable when walking along the street (see Figure 4).

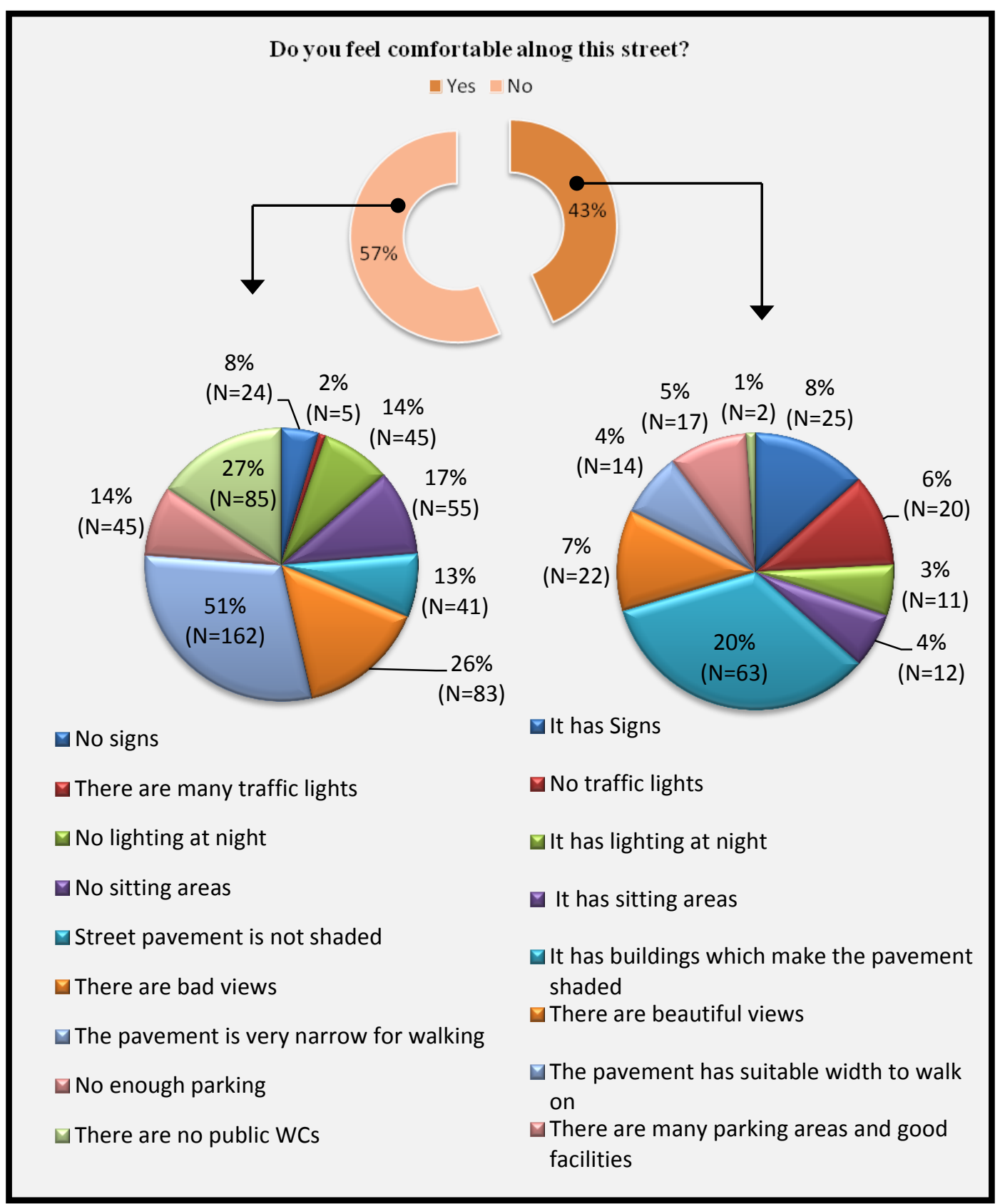

Figure 4: Reasons why respondents feel uncomfortable when they walk along the street 
It was also observed that multi levels of pavements as well as the presence of a large number of stalls surpassing sidewalk space and even on the street space affect the comfort of pedestrians on the street. These issues lead many people to use the street space for walking instead of the sidewalk. Hence, there is a need to design the pavement and push more attention to make it comfortable for pedestrians because pavements are considered as one of the physical elements that create a feeling of relaxation, as mentioned by [32]. In addition, the sidewalk itself had many levels of the pavement, moreover, in some places it is cracked and broken that make it very hard to walk on it. That is why the most or the respondents felt uncomfortable in walking in the street.

On the other hand, the lack of public toilets along the street reduced the sense of comfort in Nineveh Street as mentioned by $27 \%(\mathrm{~N}=85)$ of the respondents in the survey. From the field interviews, many respondents confirmed that many people, especially women, suffer from the lack of public toilets in the whole of Mosul City Centre. They were forced to wait for prayer time to use the toilets of the mosques along the street or in the alleys of Mosul City Centre.

Approximately the same percentage of respondents felt uncomfortable in the Street due to the bad scenes. It was also noted that the spread of littering, the presence of destroyed and ramshackle building, as well as the spread of military points and bridges of the Iraqi army along Nineveh Street, especially at the junctions, reduced the sense of comfort to respondents. Moreover, the lack of other landscape features like road signs, lightings at night, sitting areas, and parking areas reduced the sense of comfort in Nineveh Street. Some interviewers accentuated that there is nothing in the street that makes them feel comfortable. This Street needs a lot so far, so it can be called as a street because it is just a mess. There is no sufficient parking provided. It is not supplied with lighting at night. The billboards of shops and doctors are in a mess. There are no plants in the Street. There are no road signs. The only thing there is plenty of waste and wires of private electricity generators. These problems require serious efforts by decision-makers in the Municipality of Mosul and at Mosul University who wish to improve the physical characteristics of Nineveh Street and other streets in Mosul City Centre.

These results support the view of [2], conforming the importance of road signs, lighting at night, the presence of greenery and plants, and the presence of public toilets in making the place comfortable. This is also in parallel with [33] study who found that the presence of night settings create an enjoyable environment which contributes toward a sense of place in the form of a place symbol.

On the other hand, $43 \%(\mathrm{~N}=138)$ of the respondents felt comfortable walking along this street. The main reason of that is due to the presence of buildings that shade the pavement. Other reasons such as the presence of signs, traffic lights, lighting and so forth were mentioned by a few respondents.

From these remarks, it can be seen that landscape features played an important role in making the street safe, but played a moderate role in making the street comfortable for those using the street. The lack of landscape features as one of the physical elements influenced negatively on the sense of comfort in Nineveh Street, thus influenced the sense of place.

\section{CONCLUSION}

Landscape features including soft landscape (trees) and hard landscape (street furniture) are strongly related to achieving sense of safety and comfort that in turn contribute in securing sense of place in streets. In Nineveh Street, the landscape features played a significant role in making the street safe much more in making it comfortable. It was observed that the most distinctive features that made this street safe were the continuous presence of people along the street. It was also observed that the most distinctive of these elements that made the street uncomfortable to the users was the narrowness of pavement and its bad finishing. This does not mean that the Street needs only these features to be comfort and safe for users. The diminishing of the street furniture like lighting system, billboards, sitting area, littering area, and street services like public toilets, and car parking area may lose their significant role in street recognition and orientation by street users, thus the sense of place is threatened. Furthermore, the untidy appearance of electricity generators and manholes add to the decline in the quality of view, leading to an uncomfortable environment.

Hence, urban designers and architects should identify the characteristics that are most attractive to street users to create and enhance the sense of place in places. The research has established that sense of place can be one of the factors to consider in the design of urban space and places especially, in these days when redevelopment and reconstruction of Mosul City Center are one of the options considered.

\section{RECOMMENDATIONS}

The study recommends to emphasis on the features that have a role in providing a sense of comfort, such as shaded sidewalks, comfortable seating areas, public toilets, and near public transportation places. Besides, emphasis on features that provide a sense of safety, such as the presence of a safe traffic environment, good lighting system at night, the continuous presence of pedestrians along the way, and the presence of security officers. These recommendations can be relevant as guidelines in improving the quality of places, thus giving a good sense of place. 


\section{REFERENCE}

[1] M. Najafi, and M. K. B. M. Shariff, "The Concept of Place and Sense of Place in Architectural Studies." International Journal of Human and Social Sciences, 6 (3), p. 187- 193, 2011.

[2] N. H. Ja'afar, A. B. Sulaiman, and S. Shamsuddin, "Traditional Street Activities in Kuala Lumpur City centre." International Journal of Multidisciplinary Thoughts, Vol. 2 (1), p. 93-105, 2012.

[3] S. Shamsuddinn, "Identity of Place: A Case Study of Kuantan Town Centre, Malaysia." Unpublished PhD thesis, University of Nottingham, 1997.

[4] M. M. Mustafa, "Local Identity of Mosul City in the Urban Design Academic Products." The 2th Engineering Conference of the Golden Ubeel, Mosul University, pp. 1-19, 2013.

[5] S. Al-Janabi, "Nineveh Street in Mosul: its functional importance and future." The Iraqis news agency, May 13, 2013. [Online]. http://iraqyoon.net/articles/news_details.php?detai 1s=459. [Accessed: July 15, 2013].

[6] S. Shamsuddin, and N. Ujang, "Making Places: The Role of Attachment in Creating the Sense of Place for traditional Streets in Malaysia." Elsevier Journal, 32, p. 399-409, 2008.

[7] F. A. Abbaszadeh, "Characterization of Physical Elements of Street Design." Unpublished PhD thesis. Universiti Teknologi Malaysia, Skudai, Malaysia, 2011.

[8] London Borough of Croydon, Landscape Design; Supplementary Planning Guidance No. 12, London Borough of Croydon, 2009.

[9] A. A. A. R. Hassan, and L. R. Hamid, "Effect of Furnishing Street Space on Harmony and Consistency of Construction Environment." AlTaqani Journal, 24(3), pp. A102-A119, 2010.

[10] V. Mehta, "Lively Streets Support Social Behavior." Journal of Planning Education and Research, 27(2), p. 165-187, 2007.

[11] CABE, Delivering Great Places to Live: 20 Questions you Need to Answer; Building for Life. London. Seacourt Ltd, 2008.

[12] S. L. Handy, M. G. Boarnet, R. Ewing, and R. E. Killingsworth, "How the Built Environment Affects Physical Activity Views from Urban Planning." American Journal of Preventive Medicine, 23(02), pp.64-73, 2002.

[13] G. Cullen, Concise Townscape. Great Britain: The Architectural Press, 1985.

[14] D. Appleyard, Livable Streets. United States of America, University of California Press, Ltd, 1981.

[15] N. H. Ja'afar, and I. M. S. Usman, "Physical and Transportation Elements of Traditional Street in Malaysia." European Journal of Social Sciences. Vol. 9 (4), p.669- 676, 2009.

[16] South Dublin County Council, Adamstown Street Design Guide: South Dublin County Council, Adamstown, 2011.
[17] North Shore City, Design of Streets; a Reference Handbook for High Quality Streets, North City Council, 2011.

[18] T. Telford, Manual for Streets. Thomas Telford Ltd. The Great Britain, 2007.

[19] N. H. Ja'afar, "Criteria Success in the Traditional Way to Attract Visitors: Kuala Lumpur: A Case Study." Unpublished Master Thesis. Universiti Teknologi Malaysia, Skudi, Malaysia, 2006.

[20] D. E. Gray, "Doing Research in the Real World." (4th ed). British, SAGE publication, 2014.

[21] J. W. Creswell, and V. L. P. Clark, "Designing and Conducting Mixed Methods Research." (2nd Ed.). USA. Sage Publication, Inc., 2011.

[22] Himilia "Apek Keselamatan Jalan Dan Kemudahan Pejalan Kaki Di Dalam Pusat Bandar Dr Perspektif Wanita: Kajian Kes Jalan Tuanku Abdul Rahman, Kuala Lumpur." Fakulti Alam Bina. Malaysia, Universiti Teknologi Malaysia, Skudai, Malaysia, 2005.

[23] N. Ujang, and K. Dola, "Linking Activity and Place Attachment Dimensions in Enhancing the Sense of Place." Alam Cipta, International Journal on Sustainable Tropical Design Research and Practice, 2 (1). pp. 59-67. ISSN 1823-7231, 2007.

[24] N. Ujang, "Place Attachment and Continuity of Urban Place Identity." Elsevier. pp. 156-167, 2012.

[25] J. Taylor, Science Research Methodology. New Castle, USA. Nyx Academics, 2012.

[26] K. F. Punch, "Introduction to Social Research: Quantitative and Qualitative Approaches." (3th edition). Great Britain. Sage Publications, 2014.

[27] A. Tandon, Research Methodology: Methods and Techniques. Anmol Publications Pvt Ltd, 2010.

[28] M. H. D. Al-Dewaji, "Urban renewal of the markets of Old Mosul: Planning study methods in maintaining the old commercial centres and developing Iraqi cities." Unpublished Master Thesis. Mosul University, Iraq, 1989.

[29] A. W. Al-Nuami, "Nineveh Street: The Master of Mosul Streets." Mosul City: cultural and heritage Illuminations. Al-Nuami, A. W. Ed., Baghdad: House of Books and Documents, 2012, 256-260.

[30] S. Al-Janabi, "Nineveh Street in Mosul: its functional importance and future." May 13, 2013, The Iraqis news agency. http://iraqyoon.net/articles/news_details.php?detai $\underline{\mathrm{ls}=459}$ [Accessed: July 15, 2013].

[31] N. H. Ja'afar, A. B. Sulaiman and S. Shamsuddin, "The Contribution of Landscape Features on Traditional Streets in Malaysia." ASEAN Conference on Environment-Behaviour Studies, July 16-18 2012. Bangkok, Thailand, Elsevier, 2011, p. 2-15

[32] C. Moughtin, Urban Design: Street and Square. London: Architectural Press, 2006.

[33] Lillebeye, "The Architectural Significance of the Street as a Functional and Social Arena." In the Sustainable Street: The environment, Human of 
Economic Aspect of the Street Design and Management. Norwegian Public Roads Administration, 2001.

\section{Biography}

My name is Musaab Sami Younus Al-Obeidy. I received the B.E. degree in Architectural Engineering from Mosul University, Mosul, Iraq, in 2009, and the Master degree in Architecture, specialization in urban design from University Technology Malaysia, Malaysia, Johor Bahru, in 2015. From 2015 till now, I have been working the Department of Architectural Engineering, Cihan University - Sulaimaniya, as an assistant lecturer.

\section{Google Scholar:}

https://scholar.google.com/citations?user=I3T_qTUAAA

\section{$\underline{\mathrm{AJ} \& \mathrm{hl}=\mathrm{en}}$}

\section{ResearchGate:}

https://www.researchgate.net/profile/Musaab_Al-

Obeidy/publications 